\title{
Methods of the National Check Bus Project
}

Summary

Objectives: Prevention at whe workste is considered increas ingly important. This paper describes the methods used in a nationwide prevention campaign performed at a large 5 wiss bank and a swiss Industrial company. The aim of this project was to encourage general heath awareness anong company employees. We also aimed to provide the companies with gen eral health analyses of their stat as a basis for furure healn promotion. Furthermore, new screening methods were eva luated in the field of research.

Methods: Participaton in the programme was voluntary and free of charge. The programme targeted all 25243 employees of the two companies in all regions of 5 whzerand. A mobile unit was avallable on sitg. The programme indued a written health questionnaire and medical examinations $(e, g, b l o o d$ pressure, blood tests, whrasound of the common carotid artery, osteo densitometry, examinations of the eye, etci. Analysis of indiwdual test results, information brochures, and a telephone intomation service were also provided. Based on the data of the individuals, the "health status" of the employees of the two companies was analysed. The companies did not have access to the data of the individuals. The programme ran trom August 1996 to Augus 1998.

Results: Whth a total of 10321 persons taking part in the project. the participaton rate was $1 \%$. Fon the diferent examinatons offered, patterns of participaton were identifiablsthat waxed with age, hierarchical status within the concern, body mass index, and number of physical complains of the employee. some of the varables showed the same trend for differant tests, whlle others showed opposite trends.
Conclusions: Participation in workste heath promotion programmes is depandent on a complex system of indwiwual and stuctural variables that need to be considered when planning worksite health promotion programmes. Consideration of specific target population characteristics, including motiva tons and incentives as well as structural constraints is lkely to improve participation rates in worksite healh promotion programmes anong employees.

Key-Words: Workplace - Health promotion - Screening - Gender - Hierarchy

Our grandmothers used to say: an ounce of prevention is better than a pound of cure. However, optimal methods and outcomes remain controversial ${ }^{1}$. As health promotion is in general multi-factorial, several different, but overlapping instruments and methods, such as information, education, or protection strategies can be applied at the conceptional individual level ${ }^{2,3}$. The North American and Australian approach may be to sustain healthy environments ${ }^{4}$. The European emphasis may be a combination of individual health promoting strategies and organisational development approaches 5 .

The Check Bus initiative is a health promotion project located at the workplace and made available to individuals on a voluntary basis, free of charge. The aim of this paper is to report on the methods of the nation-wide project running from August 1996 until August 1998. During this period 10321 individuals (6251 men and 4070 women) were examined using widely accepted methods as well as methods still under research consideration. 


\section{Methods}

The national information and prevention programme Check Bus was made available to all 25243 employees from all hierarchic levels within two nationwide companies (a Swiss bank and a Swiss industrial company). Employees were sent once a personal invitation asking them to participate. Employees who agreed to participate received a standardised questionnaire (59 complex items) on their general condition, physical disabilities, and environmental conditions. There were questions concerning hypertension, cholesterol, glucose and blood lipids, risk of skin cancer and cancer prevention measures for women and men. The participants were asked about physical activity, alcohol consumption, nutrition, smoking habits, drug consumption, vaccination status, psycho-social well-being, and socio-demographic variables. The questionnaire was available in the three national languages German, French, and Italian.

Physical examinations were performed by a team of specially trained doctors and nurses in a mobile unit which visited the different branches of the two companies nationwide. Participants presented their completed personal questionnaires at the reception in the Check Bus. All questionnaires were checked for completeness. Body weight and height were measured and blood samples were taken from all participants. According to project organisation, various supplementary examinations were recommended to selected groups of participants, depending on their age and sex:
For men over 40 years an ultrasound examination of the carotid arteries was recommended, for women over 40 years an osteodensitometry based on ultrasound technique was available. Employees under 40 years could take part in a fitness test which included a body fat analysis. However, every participant was free to choose a test recommended for the other age category, i.e., $<40$ or $\geq 40$, instead of the one recommended for his or her age group. Finally, all participants had the opportunity to have suspicious skin lesions, their eyesight, and intraocular pressure checked. For bivariate analyses Chi-square $\left(\chi^{2}\right)$ test and, for multivariate analyses, logistic regression models were applied using SPSS version 9.0 for the personal computer, whereby a level of two-sided significance of $\mathrm{p}<0.01$ was defined.

\section{Ultrasound osteodensitometry}

To measure the bone mineral density (BMD) ultrasound technology was applied ${ }^{6,7}$. Two variables measured most commonly are the speed of sound (SOS) and the broadband ultrasound attenuation (BUA) when the ultrasound passes through the bone ${ }^{6,7}$. These measurements correlate with the BMD of the calcaneus ${ }^{4,5,8-10}$. The well established T-score was used to compare the measured value $X(X=0.67 * x$ BUA $+0.28 * \times \operatorname{SOS}-420^{*}, *=$ constants) $)^{11}$ with the value that could be expected of a 20 -year-old woman from the same ethnic group ${ }^{12}$. T-scores $*:>-1$ were defined as normal values. T-scores between -1 and -2.5 were defined as slightly

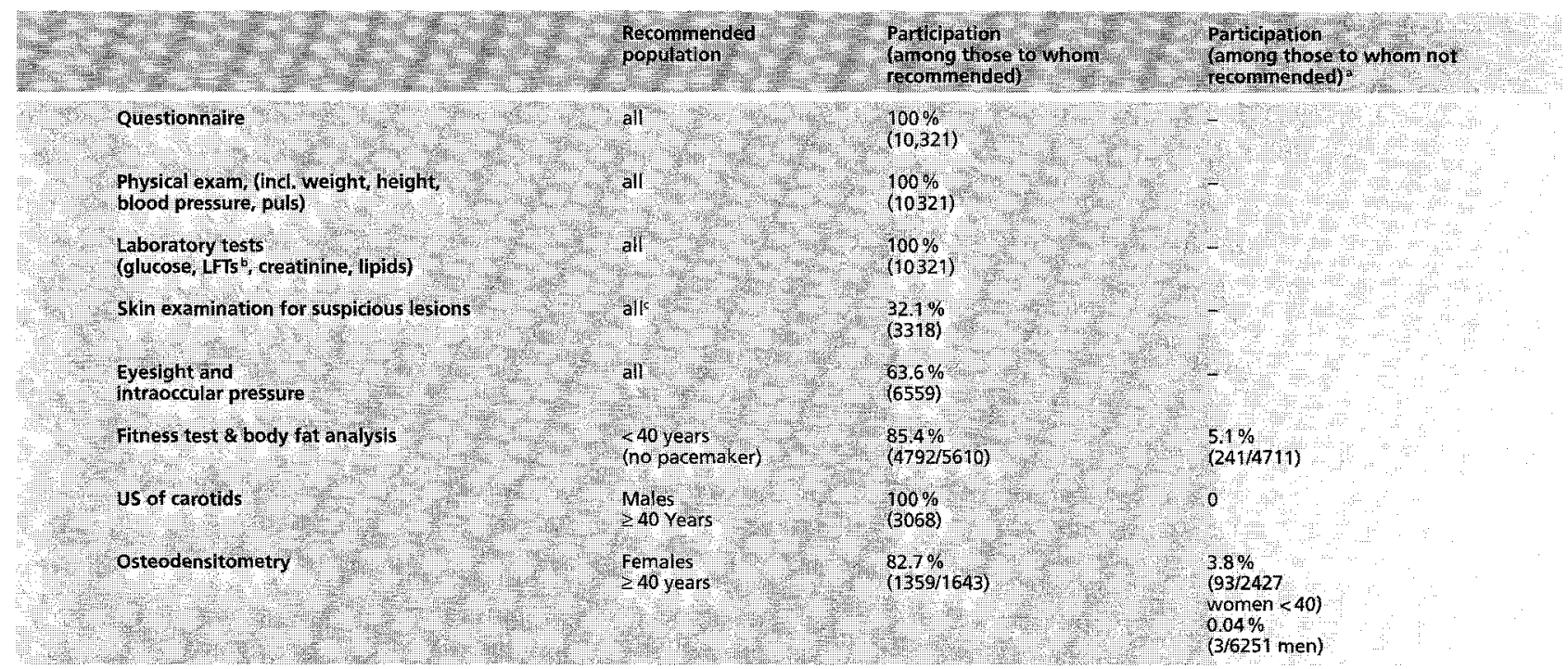

a All tests were non-complisory and every partichant had the option to choose from an alternative liev of the one recommended for his or her gender and age. $6 \mathrm{LFT}=$ iver funcion tests (gamma GT, alkaline phosphatase, GOT, GPT)

All were asked about suspicious skin cranges within the last 3 months and those who reported self I dentified suspicious skin changes were examined (suspicious skin changes within the fast 3 months: any skin Jesion with growth of more than $5 \mathrm{~mm}$ substantial increase in thickness, colour changes: lll-defined, irregular or asymmetrical edges; inflammation; constant tching or bleeding 20 .11 defined, asymmetrical andor tregularly coloured nevi with or without additional inflamed edges and birthmarks with satelite formation).

Table 1 Recommended examinations and participation rates in offered examinations

Soz.- Präventivmed. 46 (2001) 195-206

(C) Birkhäuser Verlag, Basel, 2001 
reduced values of bone density (osteopenia), in comparison with healthy younger women. Women with T-scores $<-2.5$ were defined as a risk group for osteoporosis, as suggested by WHO in $1994^{13}$. After answering questions concerning relevant medical history (hysterectomy, ovariectomy, or steroid intake), the actual measurement was performed at the calcaneus with an ultrasound densitometer (Achilles +, Lunar, Madison, USA).

\section{Bioelectrical impedance analysis (BIA)}

BIA is an electrical measurement of resistance. A homogenous electrical field with alternating current of consistent strength is produced by placing electrodes on the skin of the test person. The total resistance $=$ impedance $(Z)$ is then measured in ohm. The impedance of a biological conductor consists of resistance $(\mathrm{R})$ and reactance $(\mathrm{Xc})^{14}$. Reactance (field of capacity) describes the resistance of a condensator against alternating current. Each cell membrane functions as a tiny condensator through protein-lipid layers. Therefore, reactance is an indicator of body cell mass ${ }^{14}$. Resistance ( $R$ ) describes the pure resistance of a conductor against alternating current and is reversed proportional to the total amount of body water. Due to the high body concentration of water and electrolytes, the so-called fat free mass (FFM: total body weight minus body fat) is a good conductor of current as fat has a high resistance ${ }^{14}$. There are different models for calculating FFM. Body-weight, the resistance as well as the age and sex of the person might be taken into consideration. The formula displayed in Table 2 was used for our calculations ${ }^{15}$. After the FFM is defined, the body fat mass (BFM), the extra-cellular mass (ECM), and the body cell mass (BCM) can be determined ${ }^{16}$.

For the BFM the following definitions were used: Men with a BFM less than $10 \%$ of their weight have a decreased BFM,

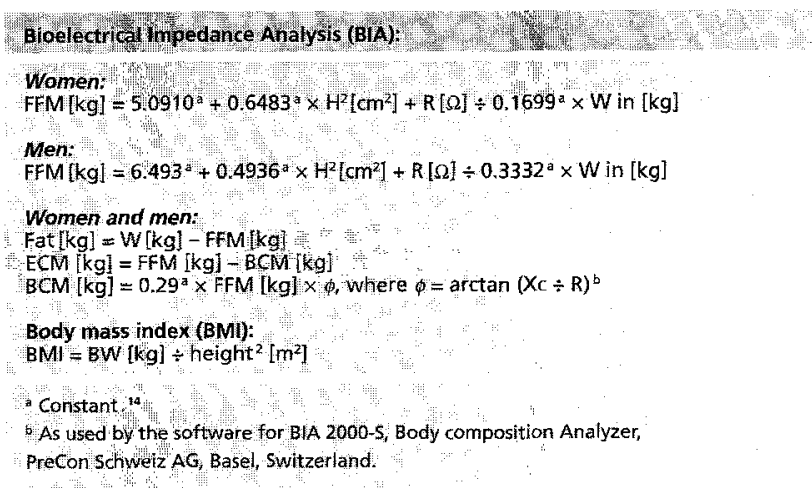

Table 2 Formulas used to calculate extra-cellular mass (ECM), body cell mass $(B C M)$ and body mass index (BMI). FFM = fat free mass, $W=$ body weight, $H=$ height, $B F=$ body fat, $R=$ resistance, $X c=$ reactance between $10 \%$ and $15 \%$ a normal BFM and over $15 \%$ an increased BFM. Women with a BFM less than $20 \%$ of their weight have a decreased BFM, between $20 \%$ and $25 \%$ a normal BFM and women with over $25 \%$ were defined as having an increased BFM. An increased BFM indicates a poor or unbalanced diet (high calorie intake). A decreased BFM indicates undernourishment. Sportspersons may have a decreased BFM due to their training schedule, (e.g., marathons) but an increased body mass index (BMI, Tab. 2). The $\mathrm{BCM}$ is mainly determined by the muscle mass. A high BCM means a big muscle mass (bodybuilders, athletes etc). A low BCM means a small muscle mass (e.g., katabolic situation due to lack of nutrition, muscular dystrophy).

The following definitions were used for the BMI: people with a BMI below 19 were regarded as being underweight, people with a BMI between 19 and 25 were considered as having normal weight, people with a BMI of 25 through 30 were defined as being overweight, and people with BMI over 30 were defined as obese.

After a participant was correctly connected to the analyser (BIA 2000-S, Body Composition Analyzer, PreCon Schweiz $\mathrm{AG}, \mathrm{Basel}$, Switzerland) the resistance was measured. Three seconds after switching on the analyser the results were read and registered. The resistance expected was defined between $250-750 \Omega$. Results outside this range were considered indicative of a measuring error.

In the Check Bus, participants with pacemakers were not allowed to have a bioelectrical impedance analysis, despite the fact that no complications are described in the literature. Pregnant women were also excluded from the examination as results would have been invalidated ${ }^{17}$. To achieve optimal results, participants were instructed in advance not to eat or drink anything for two hours before the examination, no physical exercise for $12 \mathrm{~h}$ and no alcohol intake for $24 \mathrm{~h}$ preceding the examination.

\section{Fitness check}

The fitness check included an endurance test. This measures the capacity of the cardio-vascular system, the lungs, and muscles to transport oxygen. Flexibility of the lumbar spine, and the elasticity of the hip extensors were assessed. Strength of the upper body (to measure dynamic co-operation of shoulders, arms, and chest), and strength of the trunk (to measure dynamic stamina or strength of the abdominal muscles) were also evaluated. To assess endurance, the participant continuously stepped up and down a step $30 \mathrm{~cm}$ high for three minutes, maintaining a constant speed, directed by a standardised audio tape. Five seconds after this exercise was completed, the pulse was taken for 60 seconds and registered. 
To assess flexibility, the participant sat on the ground, legs stretched with the soles of the feet (without shoes) against a wooden box. The participant stretched trunk and arms forward as far as possible and the distance between the fingertips and box was measured.

To assess the strength of the upper body, male participants were required to do push-ups with the body straight from toes to shoulders, women from knees to shoulders. They had to perform as many push-ups as possible in one minute. The test was stopped if they paused for more than three seconds. The total number of push-ups was registered.

To assess the strength of the trunk, participants lay on their back, both knees bent at an angle of 90 degrees, feet flat on the ground, and hands placed behind the neck. The examiner held to participant's feet firmly on the ground. For one minute the participant performed as many sit ups as possible. If the participant paused for more than three seconds, the test was stopped. The number of performed sit ups was registered.

After the fitness test the personal results were compared with standard values, based on results of healthy US Navy members of the same age and $\operatorname{sex}^{18}$. The results were given in percentiles. The percentile " 50 " corresponds to the standard value. If a participant had a percentile of 75 , this means, that in his/her age and sex group $74 \%$ of US Navy members performed worse than the participant ${ }^{10,18}$.

\section{Detection of atherosclerosis}

Screenings for pre-clinical atherosclerosis are mostly based on the early detection of risk factors such as hypertension and serum lipids. Advances in ultrasound techniques now offer a direct non-invasive screening method. It allows the visualisation of lesions in the common carotid artery and the early detection of endothelial alterations as growth of the intima media. This screening method can also detect atherosclerotic plaques. Atherosclerotic changes in these vessels correlate with changes in the coronary arteries ${ }^{19}$. Carotid ultrasound examinations were performed in the Check Bus by specially trained physicians with an ultrasound scanner (SONOLINE Versa Pro, 7.5L40 linear array, Siemens). The left and right common arteries were scanned for the presence of atherosclerotic plaques and wall thickness. If plaque was present, the maximal thickness of the plaque was measured and velocity flow measurements were performed. In addition, the HDL-quotient of the participants who had an ultrasound of the carotid arteries was determined.

\section{Dermatological examination}

A dermatological examination was performed when participants stated that they had noticed one of the following suspicious skin changes with the last three months: any skin lesion with growth of more than $5 \mathrm{~mm}$; substantial increase in thickness; colour changes; ill-defined, irregular or asymmetrical edges; inflammation; constant itching or bleeding ${ }^{20}$. Ill-defined, asymmetrical and/or irregularly coloured nevi with or without additional inflamed edges, and birthmarks with satellite formation were considered to be suspicious and further examination by a dermatologist was recommended.

\section{Eye tests}

Professional opticians performed three eye examinations (eyesight, objective refraction, and intraocular pressure) under medical supervision. Information on previously prescribed corrections of vision (glasses, lenses), the possession of a driving license, measurement results of the objective refraction (sphere of bulbus, cornea cylinder, axe length of bulbus) of the uncorrected vision (SC), and the corrected vision (CC) as well as the internal eye pressure were registered.

The colloquial term "eyesight" was defined as the ability to see with correction (= visus cum correctione) ${ }^{21}$. The ability to see without correction (= visus sine correctione) was defined as the "natural vision" ${ }^{21}$. If not specified, the term vision was used for the uncorrected sight. Due to space limitations in the Check Bus, a sign projector and three mirrors were used to compensate for the short distance. Participants had to read letters of different sizes from an optotype board. Natural and corrected vision were measured separately for each eye and the results were registered.

In order to determine the objective refraction, the participant was placed in front of a refractometer ("Nideck Auto Refraktometer AR-800") ${ }^{22}$. While the person was looking relaxed at the screen, three consecutive measurements were taken. The same process was repeated for the other eye and the mean values for each eye were registered. The axis length of the bulbus, the refraction capacity of the bulbus sphere and the lens cylinder were measured.

The pressure on the inner wall of the eye is called intraocular pressure and can be measured by exerting pressure on the cornea. The measurements were performed by a tonometer ("Nideck NT 2000 Noncontact Tonometer") ${ }^{23}$ by using a jet of air released after centring the cornea. The median of the three measurements was registered.

Intraocular pressure up to $22 \mathrm{mmHg}$ was defined as "normal" 21 . Participants who had an intraocular pressure exceeding $22 \mathrm{~mm} \mathrm{Hg}$ were advised to seek further medical examination. 


\section{Personal information for participants}

After the examinations, all participants had the opportunity to discuss their individual test results with the medical staff (nurse or, if necessary, with a doctor) for clarification. The individual written summaries of the results in German, French, or Italian were sent to each participant's home address to ensure confidentiality. A specially designed Check Bus information booklet called "Guide for Your Health", was also enclosed in the language requested by the participant (German, French, or Italian). The guide book also contained further information on ,who and where to ask", including addresses and phone numbers of relevant institutions. All participants had the opportunity to call an especially installed hotline at the Check Bus office to inquire about their personal results. Participants with results needing further clarification received a letter for their physician with the relevant findings and data.

\section{Results}

The overall participation rate was $41 \%(n=10321, n$ total $=$ 25243). The age distribution was as follows (men/women): mean 39.9/37.3, median 39.0/35.0, SD 10.8/11.3 (Tab. 3). The proportion of bank employees was $83.9 \%$. The participation rate of the bank employees was highest among the age group 30 to 49 (men $60.5 \%$, women $49.6 \%$ ), with those under 30 (men $18.1 \%$, women $32.1 \%$ ) and those over 50 (men $21.4 \%$, women $18.2 \%$ ) participating less often (Tab. 4). We did not have access to equivalent demographic data of employees of the industrial company, making a comparison impossible. Also, we did not have access to individual demographic data of non-participants of bank employees. This lack of individual data precludes any multivariate analyses of general participatory patterns. However, among participating employees in the Check Bus project, we were able to analyse the participation patterns for individual examinations that were differentially recommended to participants according to age and gender.

For the ultrasound of the carotids, all employees to whom the examination was recommended (men age 40 or older), and none of the employees to whom it was not recommended, participated.

In the measurement of bone density, $82.7 \%$ (1359) of those to whom the examination was recommended (1643 women age 40 or older), participated, whereas only $1.1 \%$ (96) of those to whom it was not recommended (6498) chose the examination. For those to whom the examination was recommended, the following variables were associated with higher participation: older age (OR 1.03, $p=0.009$ ), lower hierarchy (OR 5.3 for low-level vs high-level and OR 4.1 for low-level vs mid-level, $\mathrm{p}<0.001$ for both comparisons), industry employee (OR 4.1, $\mathrm{p}=0.002$ ), higher BMI (OR 1.1, $p<0.001$ ), and more physical complaints (OR 1.1, $p<0.001$ ). For those to whom it was not recommended, higher hierarchy (only mid-level vs low-level employees, OR 2.5, p = 0.004 ), lower BMI (OR 1.1, p =0.003), and more physical complaints (OR 1.1, $\mathrm{p}<0.001)$ were associated with higher participation.

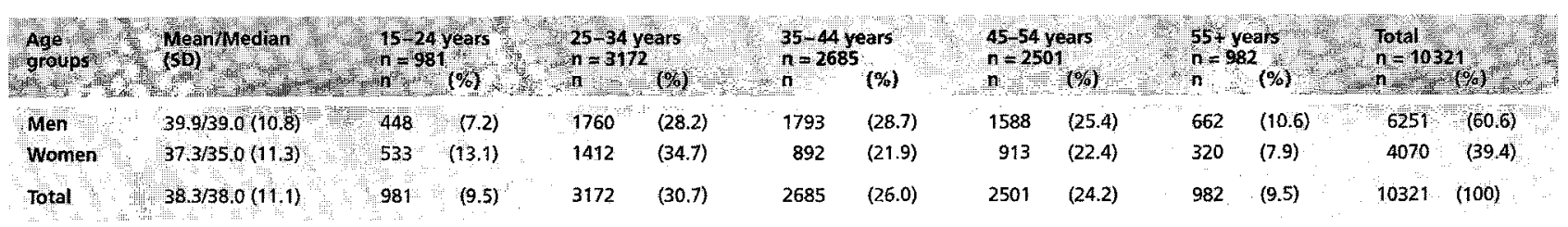

Table 3 Distribution of age and sex of the participants in the mobile work site health promotion programme Check Bus

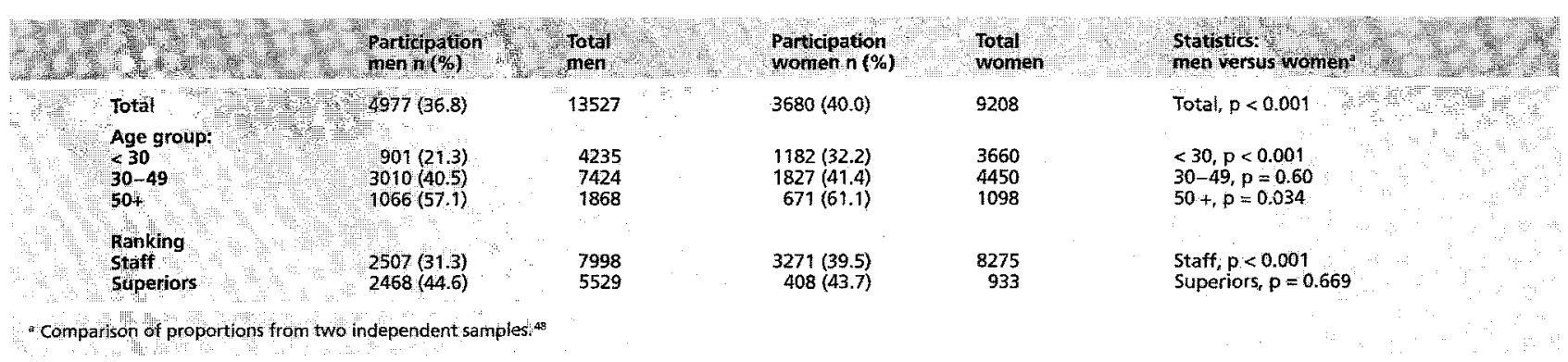

Table 4 Detailed participation rates of the bank company. Demographic description of age groups and ranking (absolute and percentage values) of the participants versus all employees of the bank company

Soz.- Präventivmed. 46 (2001) 195-206

(9) Birkhäuser Verlag, Basel, 2001 
In the bioimpedance analysis (body fat mass), $86.1 \%$ (4792) of those to whom the examination was recommended (5610 men and women younger than 40), participated, while only $5.1 \%$ (241) of those to whom it was not recommended (4711) decided to choose this examination. The variables that were associated with higher participation in bioimpedance analysis among those to whom it was recommended were: younger age (OR 1.1, $\mathrm{p}<0.001$ ), lower hierarchy (only low-level vs high-level employees, OR 2.1, $\mathrm{p}<0.001$ ), industry employee (OR 2.2, p<0.001), lower BMI (OR 1.1, p < 0.001), and fewer physical complaints (OR 1.03, $p=0.005$ ). The variables associated with higher participation among those to whom the examination was not recommended were: younger age (OR 1.2, $\mathrm{p}<0.001)$ and lower BMI (OR 1.1, p < 0.001).

All participants filled out the questionnaire, underwent a basic physical examination, and blood tests were made. A total of 3068 men age 40 and older $(49.1 \%$ of all male participants) had an ultrasound evaluation of the carotid arteries, 1359 women age 40 and older (33.4\% of all female participants) had an osteodensitometry, 4694 (45.5\%) persons participated in the fitness test, $3318(32.1 \%)$ persons received the visual screening for melanoma, 5085 (49.3\%) received the body fat analysis and $6559(63.6 \%)$ persons had an eye examination.

The most frequent initial question in health survey questionnaires "How would you describe your health at present?" was answered with "excellent" by 2511 people $(24.5 \%)$, with "good" by 6239 people $(60.9 \%)$, with "mediocre" by 1420 people $(13.9 \%)$, and with "poor" by 77 people $(0.8 \%)$. Significantly more men indicated that their health was "excellent" $(1593=25.6 \%)$ or "good" $(3805=61.2 \%)$ than women did ("excellent" 918 (22.8\%) and "good" 2434 $(60.4 \%)$, whereas more women than men chose "mediocre" (645 women $(16.0 \%), 775$ men $(12.5 \%)$, (Mann-Whitney Test, $\mathrm{p}<0.001)$ ). For nearly $3 / 4(74.1 \%)$ or respondents the current health status was their usual health status. For $16.5 \%$ the current health status was worse than usual, while for $9.5 \%$ it was better than usual. In terms of physical complaints, the majority of participants had experienced relatively few physical problems. One third of participants (3437/33.3\%) had had two or less minor physical complaints during the four weeks preceding the survey, while 6181 participants (including the $3437 / 60 \%$ ) had experienced one major or less five minor physical problems. 849 people $(<8.2 \%)$ reported having experienced three or more major physical problems and less than $1 \%$ complained of having had four more major physical problems. Table A1 displays a selection of results including cholesterol, HDL-quotient, blood pressure, BMI, and body impedance measurements.
Osteodensitometry revealed that 753 women age 40 or older $(55.4 \%)$ had normal bone density, 511 (37.6\%) had osteopenia, and $95(7.0 \%)$ had osteoporosis $(82.7 \%$ participation rate among women age 40 or older), as defined in the methods section. Of 2427 women under 40 years of age, $93(3.8 \%)$ chose this test. The proportions of the three categories, osteoporosis, osteopenia, and normal, were not significantly different from those in the older age category $(59.1 \%, 33.3 \%$, and $7.5 \%$; Fisher's exact test $p=1.00)$. Not surprisingly, the proportion of those with osteoporosis increased significantly with age (35-44: $4.8 \%, 45-54: 6.5 \%$, 55 or older $10.9 \%$, Mantel-Haenszel $\chi^{2}$ for linear-by-linear association $=18.4, \mathrm{p}<0.001$; Pearson Correlation for age and T-score $=-0.133, \mathrm{p}<0.001$ ).

Atherosclerotic plaques in the common carotid artery were detected in $339(11.0 \%)$ of the 3068 men age 40 or older taking part in this examination (none of the younger than 40-year-old men nor women any age chose this exam). The proportion of men with plaques of the common carotid artery detectable by ultrasound progressively increased with age ( $4.3 \%$ between age 40 and $44,10.6 \%$ between age 45 and $54,20.4 \%$ between age 55 and 64 , and $33.3 \%$ among men older than 65 , Mantel-Haenszel $\mathcal{X}^{2}$ for linear-by-linear association $=94.3, \mathrm{p}<0.001$ ).

BIA was done on 5033 participants $(48.8 \%$ participation overall, 4792 or $85.4 \%$ participation among those younger than 40 years of age; 241 or $5.1 \%$ of those age 40 or older chose this test) and an increased percentage of fat mass according to the definitions was found in 3195 participants $(63.5 \%)$. Normal fat mass was found in 1330 participants $(26.4 \%)$ and in 508 participants a decreased fat mass $(10.1 \%)$ was detected. According to the accepted definitions of obesity ${ }^{24}$, obese people made up 513 or $5.0 \%$ of the participants (men: 309 or $4.9 \%$; women: 204 or $5.0 \% ; \chi^{2}=0.03$, $\mathrm{p}=0.86$ ), overweight were 2709 or $26.3 \%$ (men: 2102 or $33.7 \%$; women 608 or $15.0 \% ; \chi^{2}=443.4, \mathrm{p}<0.001$ ), normal weight had 6514 or $63.2 \%$ (men: 3730 or $59.7 \%$; women: 2784 or $68.8 \% ; \chi^{2}=82.4, \mathrm{p}<0.001$ ), and underweight people made up 569 or $5.5 \%$ (men: 104 or $1.7 \%$, women: 465 or $\left.11.5 \% ; \chi^{2}=451.7, p<0.001\right)$.

\section{Discussion}

In this report the methods of the Check Bus Project are introduced. The results contain only a selection of our findings. The participation rate of $41 \%$ (10321 of 25243) is comparable to other workplace health promotion programmes. A health promotion programme in Cincinnati, USA ${ }^{25}$ had a participation rate of $48 \%$. It is, however, significantly lower compared to directly offered health checks in general practices 
with a $74 \%$ participation rate ${ }^{26}$. In contrast to this, the OXCHECK study found that if the entire population is offered health checks systematically, the acceptance rate is lower ${ }^{27}$. The Check Bus Project was performed during a period of major restructurings within one of the companies involved. As the restructuring affected most the employees in the Frenchspeaking part of Switzerland, the participation rate was consequently lower there. We assume the company restructuring negatively influenced the participation rate. In view of this the participation rate may be regarded as rather high.

One major goal of health promotion projects is to address people less conscious of their health. Since data of the nonparticipants is missing, no conclusions can be drawn as to whether this goal was achieved. The Swiss Health Survey $1997^{28}$ which was performed during the same period of time, found that a total of $83 \%$ of the Swiss population answered the question "How would you describe your health at present?" with "fine" or "excellent." In the Check Bus study, $85 \%$ of participants replied with either "fine" or "excellent." Among our 6245 male study participants whose BMI was available, 2411 or $38.6 \%$ were overweight or obese, and among our female participants with available BMI (4061), 812 or $20.0 \%$ were overweight or obese. Corresponding proportions found in the Swiss National Health Survey in $1992 / 3$ for the same age group (15 years or older) ${ }^{29}$ were $39.2 \%$ for men and $21.8 \%$ for women, respectively. These proportions were not statistically significant $\chi^{2}=0.52$ for men and 5.1 for women, respectively, $p>0.01$ for both). With respect to the self-perceived overall health status and the distribution of overweight and obese people among men and women, these results may indicate that our population is comparable to the general Swiss population.

Men usually belong to the group of people who are less health conscious. Gender-specific health research shows that women and men differ in their willingness to undergo preventive actions such as medical check-ups or the use of medical services in times of physical complaints ${ }^{30}$. The question as to why men use preventive measures less than women and what can be done to enhance the use of such services still remains unanswered. Similarly, most studies that look at participation rates in worksite health promotion programmes and at factors that determine healthy behaviour have found that women, in general, tend to participate more in worksite health promotion programmes and also tend to adhere to a healthier lifestyle ${ }^{31-35}$. However, more differentiated studies looking at differences within female gender also showed the significant variation among women and multiple factors, such as life stressors, education, $\operatorname{mood}^{36}$, role as a caregiver ${ }^{31}$, type of programmes offered ${ }^{34,35}$, as well as out-of-work activities $^{37}$. Clearly, more qualitative components need to be incorporated into worksite health promotion program evaluations in order to make worksite health promotion more efficient and appropriate for the target population. Against this background, it is not surprising that the participation rates among women and men varied depending on the age group.

In our sample, female bank employees' participation was only significantly higher among the youngest age group (Tab. 4), under age $30(p<0.001)$, while in the oldest age group (age 50 years or older), there were more men who participated $(\mathrm{p}=0.034)$.

An interesting finding was that, for bone density measurement, BMI and physical complaints were inversely associated with participation among those to whom the examination was recommended and among those to whom it was not recommended. This was not the case for BIA, and we suspect that, as long as there are no other barriers, such as physical exercise (required for BIA, which was linked to the fitness check), overweight, or obese people, and people with physical complaints tend to utilise health promotion programmes differently.

However, the odds ratios for these variables were rather small compared to those for structural variables, such a variables, such as hierarchy wind employer (bank vs industry), emphasizing the importance of structural, as opposed to personal, factors that need to be taken into account when planning worksite health promotion programmes, as other previous studies have shown ${ }^{38,39}$. Finally, self-efficacy, reported in the literature as one of the more important factors for participation in worksite health promotion programmes ${ }^{39,40}$, may actually mirror an employee's realistic judgement of structural barriers.

Employee health promotion programmes typically involve education programmes, cholesterol, blood pressure, diabetes or other similar screening programmes, smoking cessation programmes, drug/alcohol testing and counselling programmes, exercise facility or activity programmes, and recreational activity programmes ${ }^{41}$. We chose a novel methodological approach in the Check Bus by complementing traditional modules with modern technical devices for osteodensitometry, ultrasound of the common carotid artery, computerised body composition measurements, and intraocular pressure measurements. Some of these new and partly still controversial technologies may have been more attractive to our cohort of bank and industry employees than the traditional health promotion interventions at worksites. If just the traditional health promotion modules frequently available in private practice and low budget health promotion interventions at worksites had been offered, people may have been less interested. Also, the fact the that Check Bus was not a 
permanent institution may have influenced the participation, and potentially, a permanent institution of a worksite health promotion programme may have an impact on participation in both directions, as well as a differential impact on different subgroups.

In addition to the described basic examinations, more specialised examinations were available to the participants according to gender and age. However, participants were able to choose a different module offered by the health promotion programme as an alternative to the one recommended. For the bone density measurements and BIA, employees of lower hierarchy and from the industry tended to participate significantly more often than those of higher hierarchy and from the bank. Participation rate in bone density measurement (employees age 40 or older) was higher for the older, of higher hierarchy and those with more physical complaints. Conversely, for the bioelectrical impedance analysis (younger than age 40), participation rate was higher for the younger, of lower hierarchy and those with fewer physical symptoms. While some of these opposing trends are explained by the fact that BIA was offered to participants in conjunction with the fitness check, which may have prevented people with higher BMI and more physical complaints to participate. However, given the recommended age range for BIA of less than age 40 and 40 years or older for the bone density measurement, age itself is unlikely to have been the reason for the difference in participation.

Evidence on the efficacy and usefulness of individual health promotion activities is in discussion at present $t^{1,2,9-11}$. The OXCHECK project concluded that the benefits of health checks were sustained over three years. The main effects being dietary changes and reduction in the level of cholesterol concentrations ${ }^{42}$. The LIVE FOR LIFE health promotion programme on changes in workers' absenteeism concluded that programme participants experienced an average of 4.6 fewer absentee hours compared with non-participants, after controlling for baseline absenteeism, gender, race, education, and age ${ }^{43}$. Another mobile worksite health promotion programme in Arizona concluded that benefit-tocost ratio for the entire programme resulted in a saving of $\$ 3.60$ for every dollar spent. This programme showed that mobile worksite health promotion programmes can be effective in reducing employee health care expenditures among both programme participants and non-participants ${ }^{44}$. Finally, a mobile worksite health promotion programme in Oklahoma, USA, reduced employee health risks by measuring blood pressure, cholesterol total and total/high-density lipoprotein ratio, body fat percentage, and submaximal fitness ${ }^{45}$.

Some of the limitations of this study may be as follows. First, our population from a bank and an industry are not neces- sarily representative for other banks or other industry nor for the Swiss population at large. Nevertheless, self-perceived health status was comparable to the results of the 1997 Swiss Health Survey. Also, our sample from two major companies allows us to control for some unknown potential confounders in future multivariate analyses. Second, the voluntary nature of the participation makes the study vulnerable to selection bias. For quite obvious reasons, most studies of worksite health promotion programmes do not report participation data ${ }^{32}$. Data on whether healthier employees tend to participate more in worksite health promotion programmes are inconsistent. In some studies, healthy employees were neither more likely to be intenders ${ }^{46}$ nor to be actual participants ${ }^{38}$ in worksite health promotion programmes. In another study, employees at lower behavioural risk tended to participate more in worksite health promotion programmes ${ }^{34}$. These divergent findings may simply be an indicator of the complexity of factors that determine participation, including personal and job factors, which are, among other factors, intimately related to gender $32,37,39$. Third, the cross-sectional nature of the study cannot answer questions as to whether these worksite health promotion programmes have any tangible effects on health outcomes. As already men mentioned, worksite health promotion programmes may have an economic impact for the employer ${ }^{44}$, but they don't seem to improve job satisfaction ${ }^{47}$. Aldana has shown some positive effects on cardiovascular health risk factors of employees through implementation of worksite health promotion programmes over a period of one and a half years ${ }^{45}$. But even then we do not know the long-term benefits of such interventions on risk factor modification or health outcomes, such as coronary heart disease.

In this project, a large bank and an industrial company in Switzerland invested in a mobile worksite health promotion programme to screen employees for individual health risk and pursue risk reduction through counselling, health education, and referral to appropriate medical treatment. We have conducted a follow-up survey in order to obtain participants' feed-back on perceived usefulness of the Check Bus project as well as on possible behavioural modifications that resulted from the participation. The results have been analysed and will be published in the near future. Finally, the data set from the project contains information on many psychosocial variables as well as physical measurements of some known health risk factors and actual changes in the end organs. This data set from a large sample will enable us to explore more in depth the interface between psychosocial factors and health risk factors as well as participants' perceived health. 


\section{Conclusions}

When planning worksite heath promotion programmes, consideration of structural aspects of interventions is likely to be just as important, if not more important, than individual factors. Consideration of specific target population characteristics, including motivations and incentives as well as structural constraints may improve participation rates in worksite health promotion programmes among employees.

\section{Acknowledgements}

The authors would like to thank Jane Wirz and Jenny Piket for their kind preparation of the manuscript. The Check Bus Project was supported by the Credit Suisse Group, Siemens Schweiz AG, Sanitas Health Insurance Company and Europe Assistance. There are no conflicts of interest.

Zusammentassung

\section{Methodik des nationalen Projekts "Check Bus"}

Fragestellung: Der betrieblichen Gesund heitstorderung wrot

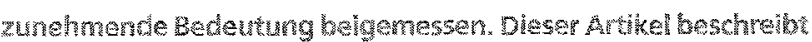
die Methoden, whe in einer landasweiten präventionskampagne ik zwet grossen Sthweizer Firmen, einer Bank und einem Indusweuntemehmen, zup Anwendung kamen. Das Ziel des frojeks war einersexts, das all gemene Gesundheits. bewusstsm der Belegschaf zu fordern, andererseits, den Unternehmen eine algemeine Gesundheitsandyse ihrer Ar. gestellun als Basis fur zukunfige gesundheltstorderungs-

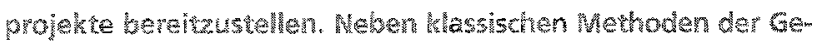

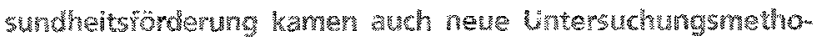
den im Forchungsbereich zur Anwendung.

Methoden: bie Teinahme am programm war frewillig und kosterlos. 025 programm richtete sich an insgesam 25243 Angestelita der beiden Unernehmen. Im check sus wurde en schrthicher Fragebogen aut Volstandigket kontrollert und

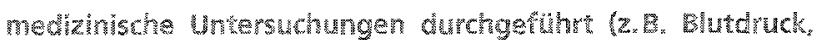
Blutest Uitwathalluntersuchung fer Halsgefässe, Messumg

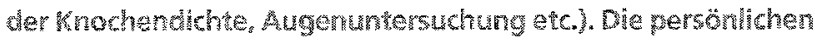
Untersuchungstesultate und eine informationshoschure wurden den Teilnekmen an thre privatadresse geschck. Fur teleTonische Auskintte wurde eire "Ho Hine" aingenchtet. Die Untemehnen ewiehen Gesundheirsberithe in anonymisherter rom. Dos Frogram lief von August 1936 bis August 1998.

Resultate: Mrsgesamt beteiligten sich 10321 personen am projekt Telhehmerquote 41\%). Fir die zorschiedenen Untersuchungen, die angeboten wurden, varierter die Telnahme-

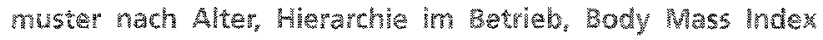

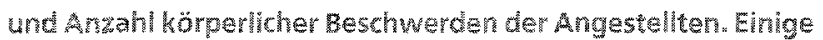
Variablen zeigten fur verschisdene Uviersuchungen, während andere entgegengesetzte Trends antwieser.

Schlussfolgerungen: Die Tehmahmerrate an Gesundheitstorderumgsprogrammen in Betriatsen ist abhängig von indwiduel-

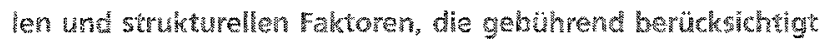

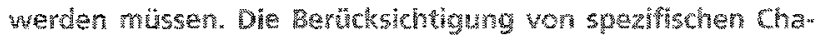

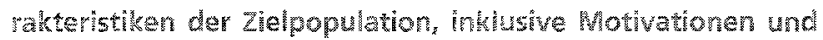
Anreize als auch strukturelle Zwinge youbssem vemutich die reinahmerate an Gesundheits robuterungspogrammen am matbeisplaz.

Désume

\section{Méthode du projet national «Check Bus»}

Objectifs: La prevention samitaire au travall prend de pius en plus dimportance. cet antide decrit les methodes unvilses lors dune campagne nationale ce prevention aupres dune banque ex diune compagne industrielle. te but de ce projet écils dine part de favoriser la perception de l'état sanitare des enpoyes, ef d"autre part d"anaysar la situation sanifaire generale des deux conpagniss, afin de taire avanker des projets d améliorations pour le futur. Outre les néthodes chas-

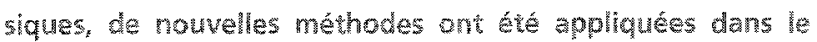
comathe de la racherche

Méthodes: La participation au programme était volontaire et gratuite. Le programme 5'adressat aux 25243 employes des deux compagnies. Sur place se trotyat un bus moble. La programme consistait en un questiontaire des examens méd" caux Ifar axemple: pression sanguine, test sangun, ultrason des artères carowdes, psteodensitometric, axamen des yeux, etco). Les résultats personnels des examens ainsi qu'une brochure dintomations ont êté envoyés à l'adresse privés des participants. poup des renseignements tétephoniques, un numero spécial avait eté installe. Les deux compagnies ont reçu rapport basé sur les données mivividulles des employés et montrant la sivuation générale. Ces compagnes nont pas su actes aux donnés individuelles. le programme a eu lleu entre aout 1996 et achut 1998.

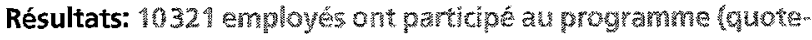
part de $4 \%$ ). Pour les diferents examents of modeles de participation étaientidentifiables selon lage. le statut professionel dans lentreptise, lindice de masse corporthe te nombre de difficulus physicues des employes. Quelques variables montralent même tendance pour differents tests, alors que d'autres présentaienà des tendances opposées. 
Conclusions: La participation a un programme de prevention sanitaite sur le leu de travall est le résultat d une interacton complake dias facteurs individuels et structurels. II taut rem specter ces facteurs dans le cadre des programmes de pren venton sanitaire sur le yeu de travall. Le fart de prendre en consideraton les caraterérstiques spécificues de la population visee, en incluant les motivatong at stimulations auss bien que les congtraintes structurelles, pat waisembiablement amelore les taux de participation des employés à des program mes depreventon sanitaire sur le leu de raval.

\section{References}

1 McCormick J. Health promotion: the ethical dimension. Lancet 1994; 344: 390-1.

2 Speller V, Learmonth A, Harrison D. The search for evidence of effective health promotion. BMJ 1997; 315: 361-3.

3 Tannahill $A$. What is health promotion? Health Educ J 1985; 44: 167-8.

4 Program management guidelines for health promotion. In: Better Health Care. Sydney: Central Sydney Area Health Service and NSW Health, 1994.

5 Grossman R, Scala K. Health promotion and organisational development: developing settings for health. Vienna: WHO, 1993.

6 Langton CM, Palmer SB, Porter RW. The measurement of broadband ultrasonic attenuation in cancellous bone. Eng Med 1984; 13: 89-91.

7 Rossman P, Zagzebski J, Mesina C, Sorenson J, Mazess $R$. Comparison of ultrasonic velocity and attenuation in the os calcis to photon absorptiometry measurements in the radius, femur and lumbar spine. Clin Physiol 1989; 10: 353-60.

8 Bundesamt für Statistik. Erste Resultate der Schweizerischen Gesundheitsbefragung 1997. Statistik Schweiz News 1998; 108.

9 Oxcheck Study Group. Effectiveness of health checks conducted by nurses in primary care: results of the oxcheck study after one year. BMJ 1994; 308: 308-12.

10 Lederer P, Schmid K, Weber A, Meixner U. Sozialmedizinische Evaluation von Einstellungsuntersuchungen bei Beamtenanwärtern. Gesundheitswesen 1997; 59: 302-6.

11 Raspe H. Gesundheit leben: Perspektiven der Prävention in einer modernen Gesellschaft. Z Ärztl Fortbild Qualitätssich 1997; 90: 741-6.

12 Achilles and Ultrasound Densitometer. Madison: Lunar Ltd. Corporate Headquarters, 1996.
13 World Health Organization. Assessment of fracture risk and its application to screening for postmenopausal osteoproenopausal osteoporosis. Geneva: WHO, 1994. (Report No. 843).

14 Kussmaul B, Döring A, Filipiak B. Bioelektrische Impedanzanalyse (BIA) in einer epidemiologischen Studie. Ernährungsumschau 1996; 2: 46 .

15 Segal K, Gutin B, Tresta E, Wang J, Itallie T. Estimation of human body composition by electrical impedance methods: a comparative study. J Appl Physiol 1985; 58: $1565-71$

16 Pirlich $M$, Plauth $M$, Lochs $H$. Bioelektrische Impedanzanalyse: Fehlerquellen und methodische Grenzen bei der klinischen Anwendung zur Analyse der Körperzusammensetzung. Akt Ernähr Med. 1999; 24: 81-90.

17 SVE. Diät-/Ernährnungsberatung. In: SVE Handbuch Teil 2; Body Composition Analysis (BCA); Grundlagen der BIA, Bestimmung der Körperzusammensetzung durch die Impedanzmessung. p. 5.

18 Berry. Berry Health: Programmübersicht Fitcheck. In: Windows 3.1 ed; 1997.

19 Taylor DC, Strandness $D E$. Carotid artery duplex scanning. J Clin Uitrasound 1987; 15: 635-44.

20 Jung EG. Dermatologie. Stuttgart: Hippokratesverlag, 1998.

21 Grehn F, Leydhecker, W. Augenheilkunde. 26. Aufl. Berlin: Springer, 1995.

22 Nideck. Nideck Auto Refraktometer AR800. In: 1996.

23 Nideck. Nideck NT 2000 Noncontact Tonometer. In: 1996

24 James WP. The epidemiology of obesity Ciba Found Symp 1996; 20I: 1-11.

25 Goetzel RZ, Jacobson BH, Aldana SG, Vardell $K$, Yee $L$. Health care costs of worksite health promotion participants and non-participants. J Occupa Environ Med 1998; 40: 341-6.

26 Dowell AC, Ochera JJ, Hilton SR, et al. Prevention in practice: results of a 2-year follow-up of routine health promotion interventions in general practice. Fam Pract 1996; 13: 357-62.

27 Oxcheck Study Group. Prevalence of risk factors for heart disease in OXCHECK trial: Implications for screening in primary care. Imperial Cancer Research Fund OXCHECK Study group. BMJ 1991; 302: $1057-60$.

28 Bundesamt für Statistik. Steigende Tendenz für gesundheitliche Risiken bei Jugendlichen in der Schweiz. Statistik Schweiz News 1998; 108 .

29 Eichholzer M, Luthy J, Gutzwiller F. [Epidemiology of overweight in Switzerland: results of the Swiss National Health Survey 1992-93]. Schweiz Med Wochenschr 1999; 129: 353-61.

30 Saltonstall $R$. Healthy bodies, social bodies: men's and women's concepts and practices of health in everyday life. Soc Sci Med 1993; 7-14.

31 Spilman $M$. Gender differences in worksite health promotion activities. Soc Sci Med 1988; 26: 525-35.

32 Glasgow RE, McCaul KD, Fisher KJ. Participation in worksite health promotion: a critique of the literature and recommendations for future practice. Health Educ Q 1993; 20: 391-408.

33 O'Quinn $J L$. Worksite wellness programs and lifestyle behaviors. $\boldsymbol{J}$ Holist Nurs 1995 13: 346-60.

34 Lewis RJ, Huebner WW, Yarborough CM, $3 r d$. Characteristics of participants and nonparticipants in worksite health promotion. Am J Health Promot 1996; 11: 99-106.

35 Kahl H, Holling H, Kamtsiuris $P$. [Utilization of health screening studies and measures for health promotion]. Gesundheitswesen 1999; 61(Spec No): S 163-8. 
36 Woods NF, Lentz $M$, Mitchell E. the new woman: health-promoting and healthdamaging behaviors. Health Care Women Int 1993; 14: 389-405.

37 Teufel NI. Diet and activity patterns of male and female co-workers: should worksite health promotion programs assume homogeneity? Women Health 1992; 19: 31-54.

38 Grosch JW, Alterman T, Petersen MR, Murphy $L R$. Worksite health promotion programs in the U.S.: factors associated with availability and participation. Am J Health Promot 1998; 13: 36-45.

39 Kronenfeld J, Kirby IL, Davis KE, Blair SN Changing health practices: the experience from a worksite health promotion project. Soc Sci Med 1988; 26: 515-23.

40 Alexy $B$. Factors associated with participation or nonparticipation in a workplace wellness center. Res Nurs Health 1998; 14: $33-40$.
41 Herbert DL, Herbert WG. Legal issues in the delivery of worksite health promotion. Occup Med 1990; 5: 851-61.

42 Oxcheck Study Group. Effectiveness of health checks conducted by nurses in primary care: final results of the Oxcheck study. BMJ 1995; 310: 1099-104.

43 Knight KK, Goetzel RZ, Fielding JE, et al. An evaluation of Duke University's LIVE FOR LIFE health promotion program on changes in worker absenteeism. J Occup Med 1994; 36: 533-6.

44 Aldana SG, Jacobson BH, Harris CI, Kelley $P L$. Stone WJ. Influence of a mobile worksite health promotion program on health care costs. Am J Prev Med 1993; 9: 378-83.

45 Aldana SG, Jacobson BH, Harris CJ, Kelley PL. Mobile Work Site Health Promotion Programs can reduce selected employee health risks. J Occup Med 1993; 35: 922-8.
46 Zavela KJ, Davis LG, Cottrell RR, Smith $W E$. Do only the healthy intend to participate in worksite health promotion? Health Educ Q 1998; 15: 259-67.

47 Peterson M, Dunnagan T. Analysis of a worksite health promotion program's impact on job satisfaction. J Occup Environ Med 1998; 40: 973-9.

48 Altman DG. Practical statistics for medical research. London: Chapman + Hall, 1990: $232-5$.

\section{Address for correspondence \\ Dr. med. Julian Schilling Institute of Social and Preventive Medicine University of Zurich Sumatrastrasse 30 CH-8006 Zurich}

Tel.: ++41 16348590

Fax: ++411 6348598 e-mail: juli@ifspm.unizh.ch

\section{Appendix}

\begin{tabular}{|c|c|c|c|c|c|c|c|c|c|c|}
\hline Varable & 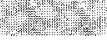 & Age (vears) & $N$ & Mean & SD & P10 & P25 & P50 & P75 & P9o \\
\hline Cholesterol $(\mathrm{mmol} / \mathrm{l})$ & : & $\begin{array}{l}15-19 \\
20-24 \\
25-29 \\
30-34 \\
35-39 \\
40-44 \\
45-49 \\
50-54 \\
55-59 \\
60-64\end{array}$ & $\begin{array}{r}162 \\
729 \\
1355 \\
1662 \\
1412 \\
1189 \\
1210 \\
1186 \\
711 \\
217\end{array}$ & $\begin{array}{l}4.4 \\
4.8 \\
5.1 \\
5.4 \\
5.6 \\
5.9 \\
6.1 \\
6.2 \\
6.2 \\
6.3\end{array}$ & $\begin{array}{l}0.8 \\
0.9 \\
0.9 \\
1.0 \\
1.0 \\
1.0 \\
1.1 \\
1.1 \\
1.1 \\
1.1\end{array}$ & $\begin{array}{l}3.5 \\
3.7 \\
4.0 \\
4.2 \\
4.4 \\
4.6 \\
4.8 \\
4.9 \\
5.0 \\
4.9\end{array}$ & $\begin{array}{l}3.9 \\
4.2 \\
4.5 \\
4.7 \\
4.9 \\
5.2 \\
5.3 \\
5.4 \\
5.5 \\
5.5\end{array}$ & $\begin{array}{l}4.3 \\
4.7 \\
5.0 \\
5.3 \\
5.5 \\
5.8 \\
5.9 \\
6.1 \\
6.2 \\
6.2\end{array}$ & $\begin{array}{l}4.8 \\
5.3 \\
5.6 \\
6.0 \\
6.3 \\
6.5 \\
6.7 \\
6.8 \\
6.8 \\
6.8\end{array}$ & $\begin{array}{l}5.3 \\
5.9 \\
6.3 \\
6.6 \\
7.1 \\
7.2 \\
7.5 \\
7.5 \\
7.6 \\
7.6\end{array}$ \\
\hline 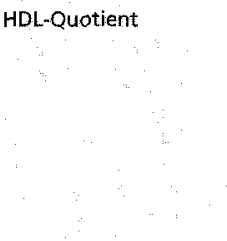 & & $\begin{array}{l}15-19 \\
20-24 \\
25-29 \\
30-34 \\
35-39 \\
40-44 \\
45-49 \\
50-54 \\
55-59 \\
60-64\end{array}$ & $\begin{array}{r}2 \\
7 \\
48 \\
119 \\
296 \\
694 \\
803 \\
752 \\
494 \\
159\end{array}$ & $\begin{array}{l}3.1 \\
3.6 \\
3.7 \\
4.1 \\
4.5 \\
4.4 \\
4.6 \\
4.6 \\
4.6 \\
4.4\end{array}$ & $\begin{array}{l}0.8 \\
0.7 \\
1.1 \\
1.3 \\
1.5 \\
1.3 \\
1.4 \\
1.3 \\
1.3 \\
1.3\end{array}$ & $\begin{array}{l}2.5 \\
2.4 \\
2.4 \\
2.6 \\
2.8 \\
2.8 \\
3.0 \\
3.1 \\
3.1 \\
2.9\end{array}$ & $\begin{array}{l}2.5 \\
3.1 \\
2.8 \\
3.2 \\
3.4 \\
3.5 \\
3.6 \\
3.7 \\
3.7 \\
3.4\end{array}$ & $\begin{array}{l}3.1 \\
3.6 \\
3.5 \\
3.8 \\
4.3 \\
4.3 \\
4.3 \\
4.4 \\
4.4 \\
4.4\end{array}$ & $\begin{array}{l}3.6 \\
4.3 \\
4.5 \\
4.7 \\
5.3 \\
5.2 \\
5.4 \\
5.3 \\
5.3 \\
5.2\end{array}$ & $\begin{array}{l}3.6 \\
4.3 \\
5.4 \\
6.1 \\
6.5 \\
6.1 \\
6.4 \\
6.4 \\
6.2 \\
6.0\end{array}$ \\
\hline 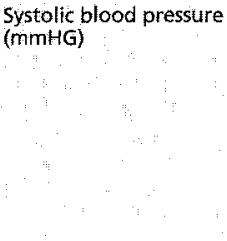 & 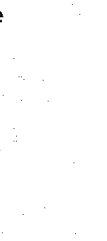 & $\begin{array}{l}15-19 \\
20-24 \\
25-29 \\
30-34 \\
35-39 \\
40-44 \\
45-49 \\
50-54 \\
55-59 \\
60-64\end{array}$ & $\begin{array}{r}179 \\
794 \\
1428 \\
1722 \\
1451 \\
1225 \\
1260 \\
1222 \\
733 \\
229\end{array}$ & $\begin{array}{l}123.6 \\
123.3 \\
123.5 \\
124.4 \\
124.9 \\
125.8 \\
128.0 \\
130.1 \\
132.1 \\
135.4\end{array}$ & $\begin{array}{l}11.8 \\
11.4 \\
12.1 \\
12.1 \\
12.3 \\
12.6 \\
14.7 \\
15.3 \\
16.4 \\
16.7\end{array}$ & $\begin{array}{l}108.0 \\
108.5 \\
108.0 \\
109.0 \\
110.0 \\
170.0 \\
110.0 \\
112.0 \\
113.0 \\
115.0\end{array}$ & $\begin{array}{l}116.0 \\
116.0 \\
115.0 \\
116.0 \\
117.0 \\
118.0 \\
118.0 \\
120.0 \\
121.0 \\
124.0\end{array}$ & $\begin{array}{l}125.0 \\
124.0 \\
124.0 \\
125.0 \\
125.0 \\
126.0 \\
128.0 \\
130.0 \\
130.0 \\
135.0\end{array}$ & $\begin{array}{l}131.0 \\
131.0 \\
132.0 \\
132.0 \\
133.0 \\
134.0 \\
136.0 \\
138.0 \\
140.0 \\
144.0\end{array}$ & $\begin{array}{l}136.0 \\
137.0 \\
138.0 \\
139.0 \\
139.0 \\
139.0 \\
146.0 \\
149.0 \\
153.0 \\
158.0\end{array}$ \\
\hline $\begin{array}{l}\text { Diastolic blood pressur } \\
\text { (mmHG) } \\
\begin{array}{ll}\mid & \\
& \end{array}\end{array}$ & 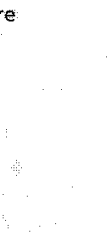 & $\begin{array}{l}15-19 \\
20-24 \\
25-29 \\
30-34 \\
35-39 \\
40-44 \\
45-49 \\
50-54 \\
55-59 \\
60-64\end{array}$ & $\begin{array}{r}179 \\
794 \\
1428 \\
1722 \\
1451 \\
1225 \\
1260 \\
1222 \\
733 \\
229\end{array}$ & $\begin{array}{l}66.8 \\
69.8 \\
71.1 \\
72.7 \\
74.1 \\
74.7 \\
76.6 \\
77.3 \\
78.4 \\
78.8\end{array}$ & $\begin{array}{r}7.7 \\
7.8 \\
7.7 \\
7.9 \\
8.3 \\
8.8 \\
9.9 \\
10.0 \\
10.2 \\
10.6\end{array}$ & $\begin{array}{l}57.0 \\
60.0 \\
62.0 \\
63.0 \\
64.0 \\
64.0 \\
65.0 \\
65.0 \\
66.0 \\
66.0\end{array}$ & $\begin{array}{l}61.0 \\
65.0 \\
66.0 \\
68.0 \\
68.0 \\
69.0 \\
70.0 \\
70.0 \\
71.0 \\
72.0\end{array}$ & $\begin{array}{l}67.0 \\
70.0 \\
71.0 \\
72.0 \\
74.0 \\
75.0 \\
76.0 \\
77.0 \\
78.0 \\
79.0\end{array}$ & $\begin{array}{l}73.0 \\
75.0 \\
76.0 \\
78.0 \\
80.0 \\
80.0 \\
82.8 \\
84.0 \\
85.0 \\
85.0\end{array}$ & $\begin{array}{l}77.0 \\
80.0 \\
81.0 \\
83.0 \\
85.0 \\
86.0 \\
89.9 \\
90.0 \\
92.0 \\
92.0\end{array}$ \\
\hline
\end{tabular}

Table A1 Selection of results. The results of examinations performed in the Check Bus, split into ten age groups (SD =standard deviation; P10, P25, P50, $\mathrm{P} 75$ and $P 90=$ percentiles $10,25,50,75$ and 90 ) 


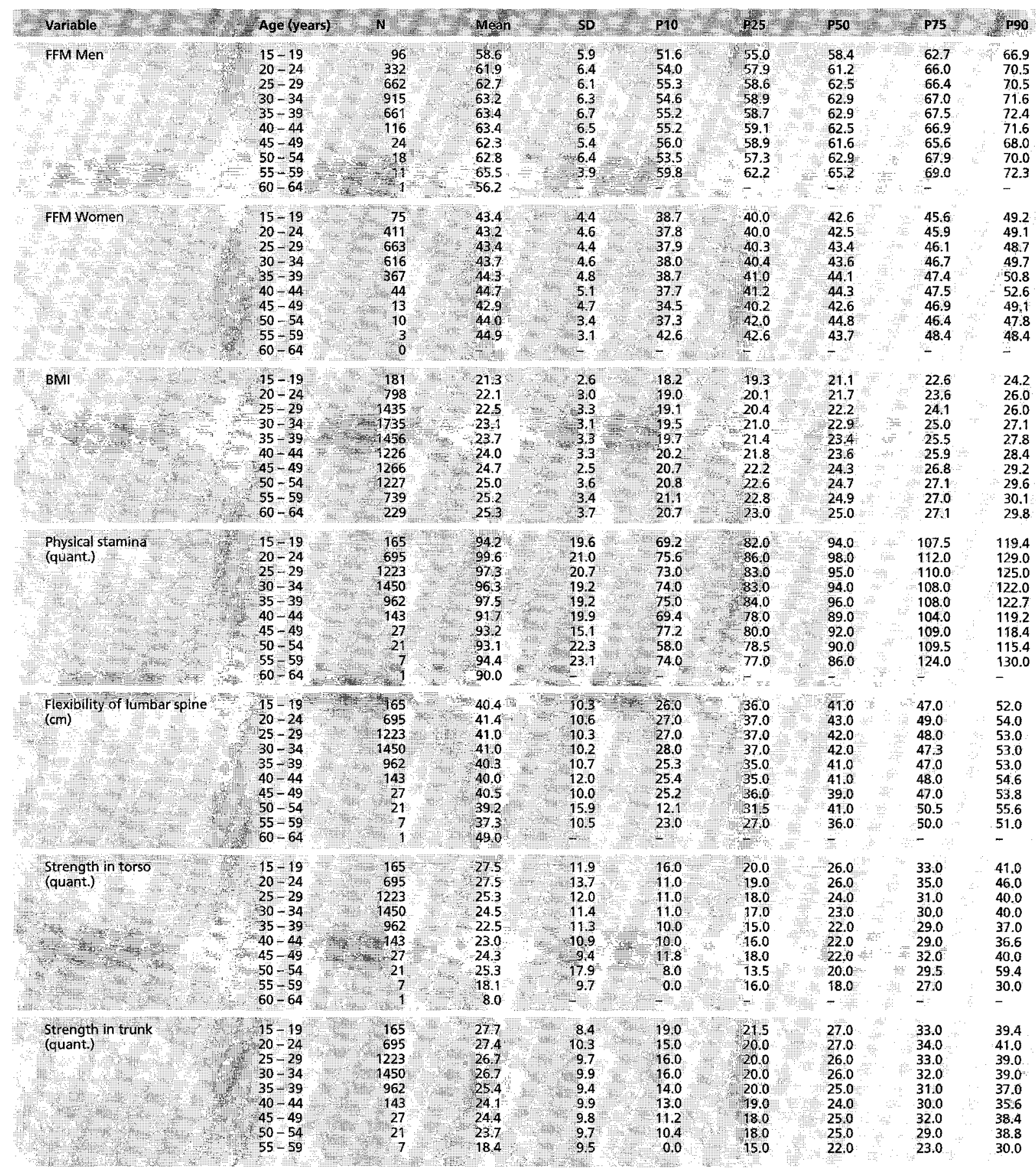

Table A1 (continued) 